\title{
Rediscovery of the San Felipe Western Giant Anole, Anolis luteogularis sanfelipensis Garrido 1975 (Squamata: Dactyloidae)
}

\author{
Seriocha Amaro-Valdés ${ }^{1}$ and Rafael Herrera-Montano ${ }^{2}$ \\ ${ }^{1}$ Instituto de Ecología y Sistemática, Carretera de Varona, \# 11835, / Oriente y Lindero, Reparto Parajón, Municipio Boyeros, \\ La Habana 19, CP 11900, Cuba (amaro@ecologia.cu) \\ ${ }^{2}$ Empresa Pesquera Industrial, La Coloma, Pinar del Río, Cuba
}

Photographs by the senior author.

$\mathrm{T}$ The San Felipe Western Giant Anole was first collected on 17 October 1970 by the Cuban herpetologists Orlando H. Garrido and Luis V. Moreno in Cayo Real, Cayos de San Felipe, south of Pinar del Río Province in Western Cuba (Garrido 1973). Two adult males and one female were on branches of White Mangroves (Laguncularia racemosa) in an area between the mangroves to the north and the sandy coast on the southern side of the cay. Those three specimens were the basis for the description of a new taxon, Anolis luteogularis sanfelipensis, endemic to Cayo Real (Garrido 1975).

Even before its formal description, this taxon was included among the most threatened vertebrates in Cuba due to its restricted geographical distribution (Instituto de Zoología 1974). Subsequent surveys (Rivera and Ramos 2000; Mancina and Beovides 2008) failed to document the presence of this taxon. Assessments at the national level assigned various threat categories to this subspecies. Rodríguez (1999) listed it as Endangered and, thirteen years later (Rodríguez 2012), as Critically Endangered. In November 1992, the Cayos de San Felipe were designated as a Faunal Refuge and in October 2010 as a National Park (Ruiz 2015).

At $1630 \mathrm{~h}$ on 22 October 2015, we observed and then collected an adult female Anolis luteogularis sanfelipensis (Fig. $1)$ in the southwestern area of Cayo Real $\left(21^{\circ} 57^{\prime} 55^{\prime \prime} \mathrm{N}\right.$,
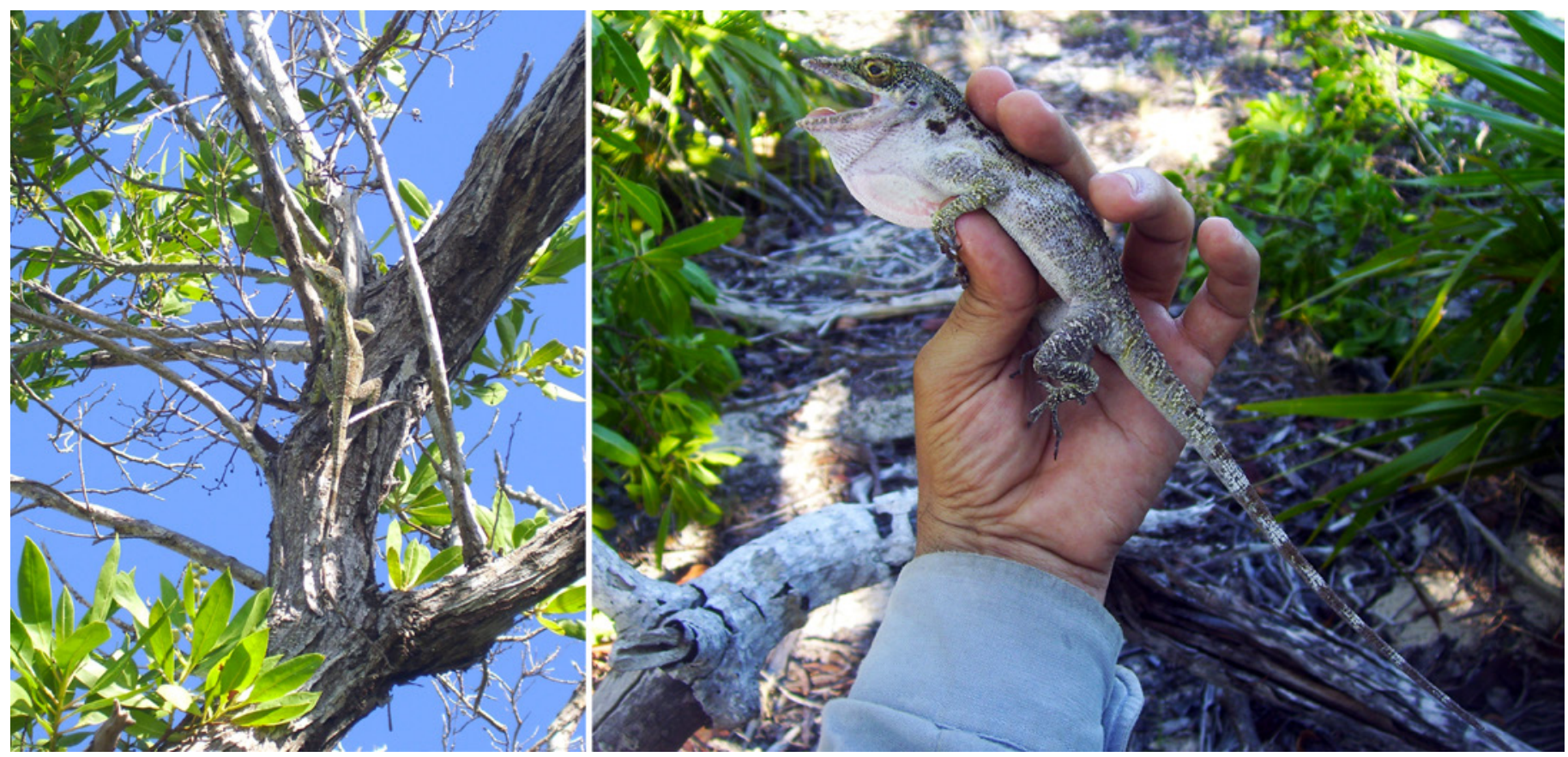

Fig. 1. An adult female San Felipe Western Giant Anole (Anolis luteogularis sanfelipensis) on a Button Mangrove (Conocarpus erectus; left) and in lateral view (right). 


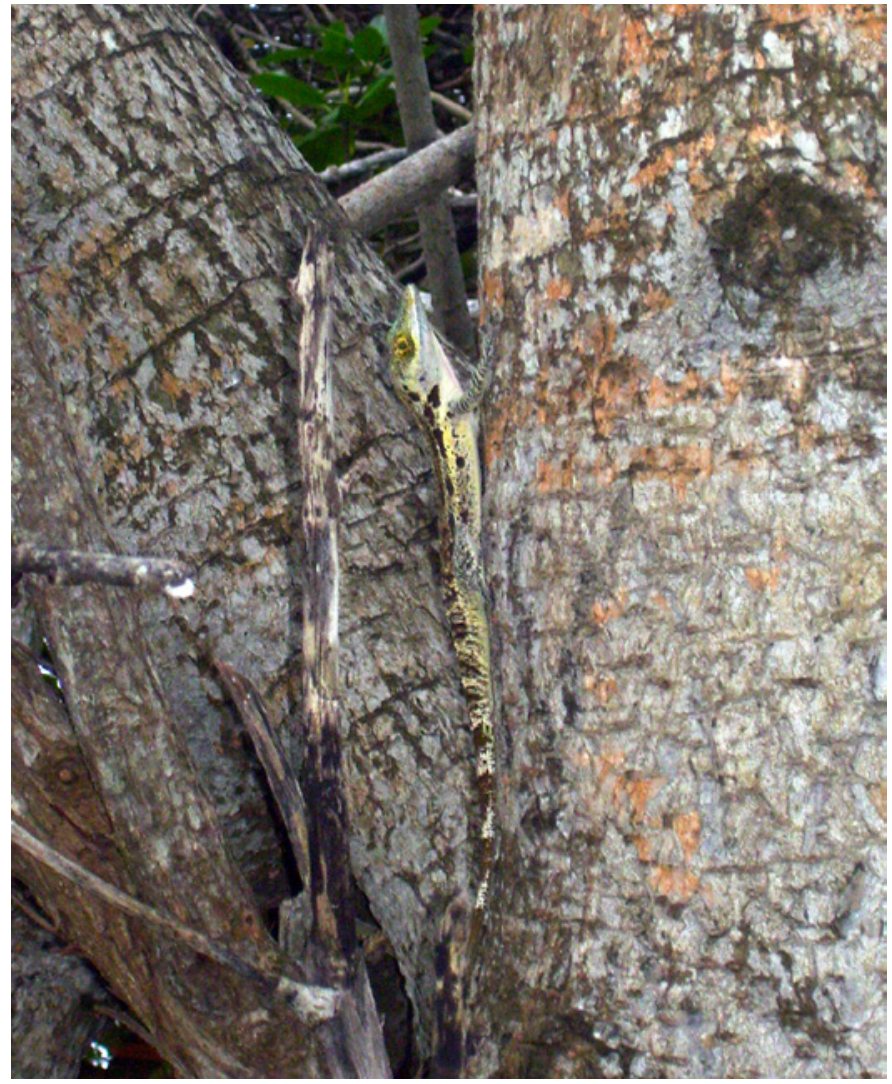

Fig. 2. An adult male San Felipe Western Giant Anole (Anolis luteogularis sanfelipensis) on the trunk of a Red Mangrove (Rhizophora mangle). $\left.83^{\circ} 36^{\prime} 47^{\prime \prime} \mathrm{W}\right)$. This individual was on a branch of a Button Mangrove (Conocarpus erectus), $3.33 \mathrm{~m}$ above sea level and just $9 \mathrm{~m}$ from the sea. The snout-vent length (SVL) was 123 $\mathrm{mm}$ and tail length was $231 \mathrm{~mm}$.

On the morning of 26 October 2015 during a subsequent visit to Cayo Real (from the headquarters in Estación Biológica in Cayo Juan García), we observed (but did not collect) two additional Anolis luteogularis sanfelipensis near the locality where the female was found about $15 \mathrm{~m}$ from the shore. At $1000 \mathrm{~h}$, an adult male (based on the presence of enlarged hemipenial bulges; Fig. 2) about $0.8 \mathrm{~m}$ above sea level on the trunk of a Red Mangrove (Rhizophora mangle), $\left(21^{\circ} 57^{\prime} 56^{\prime \prime} \mathrm{N}, 83^{\circ} 36^{\prime} 46^{\prime \prime} \mathrm{W}\right)$ evaded capture by escaping into the crown of the tree.

The second lizard, an immature individual (Fig. 3), was observed initially at $1025 \mathrm{~h}\left(21^{\circ} 58^{\prime} 02^{\prime \prime} \mathrm{N}, 83^{\circ} 36^{\prime} 48^{\prime \prime} \mathrm{W}\right)$ on the branches of a shrubby Bay Cedar (Suriana maritima) at a height of about $1 \mathrm{~m}$. In response to our presence, it jumped to a Poisonwood Tree (Metopium toxiferum).

The dorsal ground color was grayish with scattered brown scales, the venter was whitish-gray, lighter in the immature individual. The head was grayish-green. Supra- and infralabials were white in the male and immature, white spotted with brown in the female. The suprascapular stripe was not well defined, predominantly white with some yellow. The dewlap was pale pink. Large brown dorsolateral patches were larger,

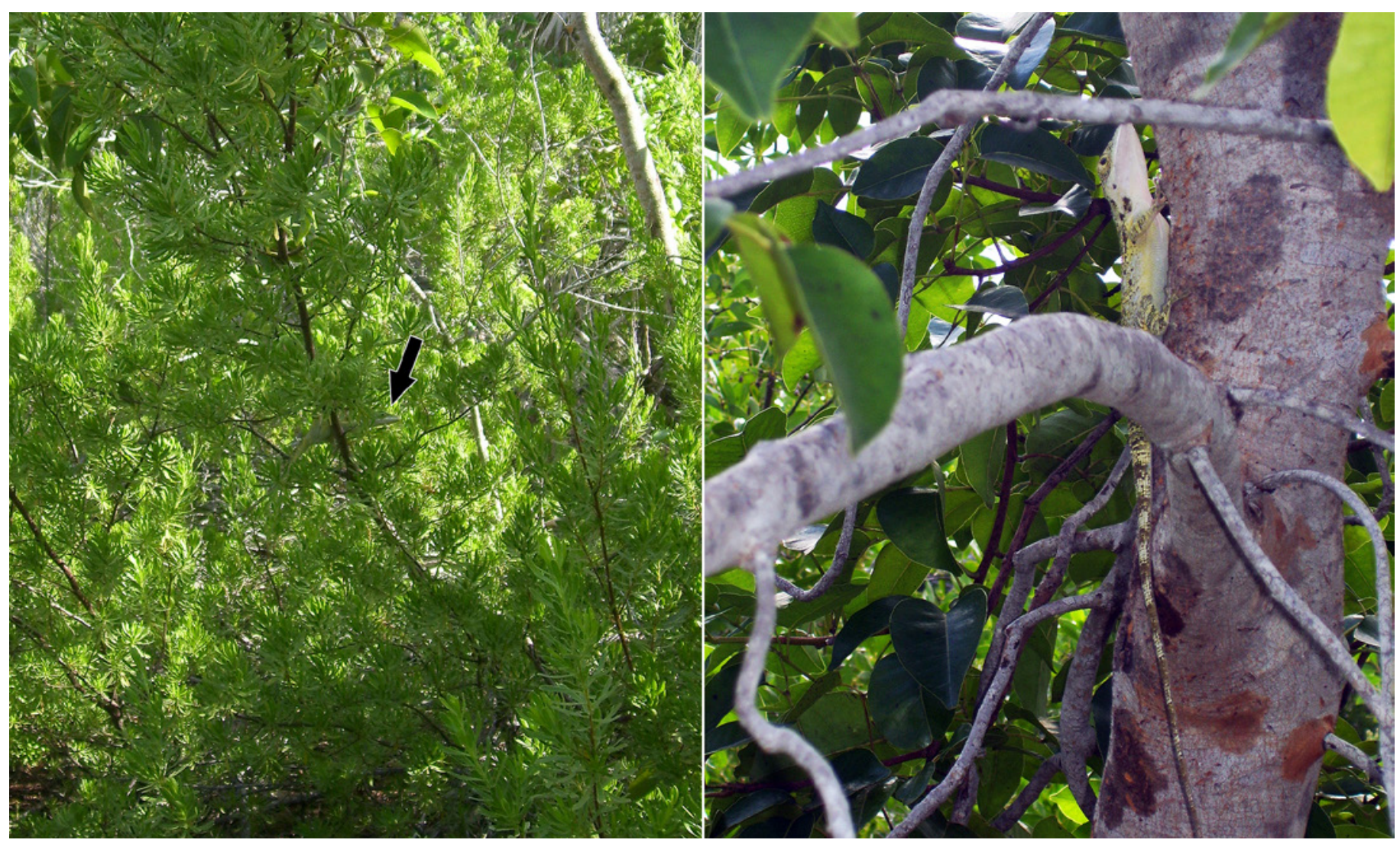

Fig. 3. An immature San Felipe Western Giant Anole (Anolis luteogularis sanfelipensis) in a Bay Cedar (Suriana maritima; left) and a Poisonwood Tree (Metopium toxiferum; right). 

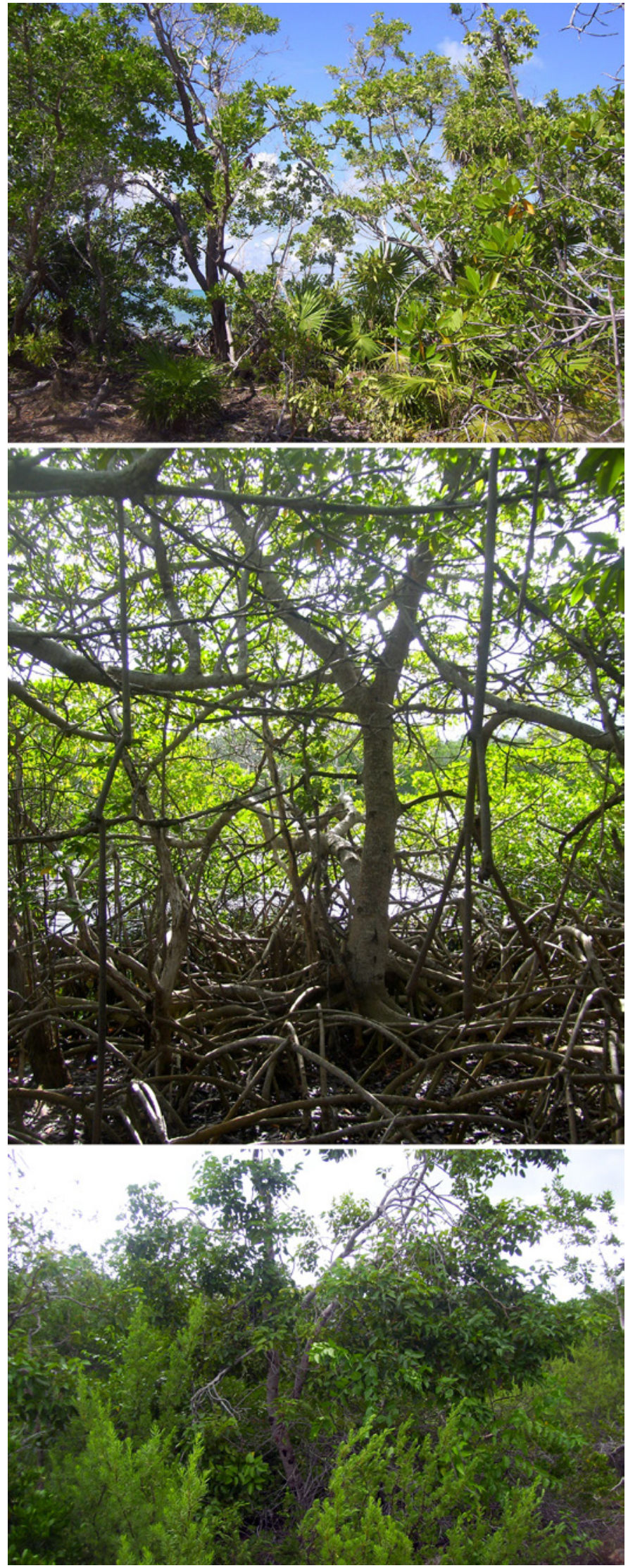

Fig. 4. Habitat of the San Felipe Western Giant Anole (Anolis luteogularis sanfelipensis) in the southwestern area of Cayo Real, Cayos de San Felipe, Pinar del Río, Cuba. This habitat is a transition zone where the sandy coast meets the mangrove stands. darker, and more abundant in the male, smaller and sparse in the adult female and immature. Legs were mostly grayish with off-white stripes and some yellow areas toward the venter. Gray and brown bands alternated on the tail.

All were in a transition zone where the sandy coastal vegetation met mangrove stands (Fig. 4). We also surveyed the semideciduous forest in the center of Cayo Real $\left(21^{\circ} 57^{\prime} 35^{\prime \prime} \mathrm{N}\right.$, $\left.83^{\circ} 35^{\prime} 21^{\prime \prime} \mathrm{W}\right)$ but found no individuals of this subspecies. These apparent habitat preferences match those described by Garrido (1973). Additional research will be necessary to confirm whether these lizards are restricted to the southwestern part of the cay or have a wider distribution. The photographs in this note are the first illustrating live individuals of this subspecies and its habitat.

Data in Garrido $(1973,1975)$ and those reported herein confirm that this taxon is not only the smallest subspecies of Anolis luteogularis but among the smallest in the entire $A$. equestris group (adult male SVL $140 \mathrm{~mm}$, adult female SVL $123-131 \mathrm{~mm}$ ), comparable only to A. pigmaequestris (adult male SVL 123-140 mm, adult female SVL 112-121 mm; Garrido 1975). Furthermore, characters such as the large brown dorsolateral patches clearly differentiate $A$. l. sanfelipensis from the other taxa in the A. equestris group. Considering that the most recent reviews of the group (Schwartz and Garrido 1972; Garrido 1975) date to a time when subspecies were more commonly described and the fact that this taxon is geographically isolated on a cay almost $30 \mathrm{~km}$ from the Cuban mainland suggest that it could (and maybe should) be elevated to the rank of species.

Although feral cats (Felis catus) have been extirpated from the cay (Garrido 1973), the survival of this apparently small, rediscovered population could be threatened by Black Rats (Rattus rattus), which persist on all of the cays (Valdés and Garrido 1978) and almost certainly prey on eggs and juvenile anoles. In addition, these lizards and other reptiles inhabiting the Cayos de San Felipe National Park could be affected by rising sea levels associated with ongoing climatic change.

\section{Acknowledgements}

The senior author is deeply grateful to Gabriel Brull (Empresa Nacional para la Protección de la Flora y la Fauna, La Habana), Carlos M. Cardoso (Oficina para el Desarrollo Integral de Guanahacabibes), Humberto N. Medina, and the staff of the Cayos de San Felipe National Park for facilitating the expedition and their hospitality. We also thank Orlando H. Garrido for help with the literature, Javier Torres (Facultad de Biología, Universidad de La Habana) for editing photographs, and our colleague Pedro P. Herrera for helping with the English translation. This note is part of the project "Colecciones zoológicas, su conservación y manejo II" (code PNAP-1310), Instituto de Ecología y Sistemática, La Habana. 


\section{Literature Cited}

Garrido, O.H. 1973. Anfibios, reptiles y aves de Cayo Real (Cayos de San Felipe), Cuba. Poeyana 119: 1-50.

Garrido, O.H. 1975. Nuevos reptiles del archipiélago cubano. Poeyana 141: 1-58.

Instituto de Zoología. 1974. Las especies amenazadas de vertebrados cubanos. Academia de Ciencias de Cuba, La Habana.

Mancina, C.A. and K. Beovides Casas. 2008 [2005]. Aves de Cayo Sijú (Cayos de San Felipe), Cuba. Poeyana 492: 1-4.

Rivera Rosales, J. and J. Ramos Reyes. 2000. Cayos de San Felipe. Un laboratorio a cielo abierto. Flora y Fauna 4: 37-40.
Rodríguez Schettino, L. 1999. Introduction, pp. 1-16. In: L. Rodríguez Schettino (ed.), The Iguanid Lizards of Cuba. University Press of Florida, Gainesville.

Rodríguez Schettino, L. 2012. Reptiles: Introducción, pp. 92-95. In: H. González Alonso, L. Rodríguez Schettino, A. Rodríguez, C.A. Mancina, and I. Ramos García (eds.), Libro Rojo de los vertebrados de Cuba. Editorial Academia, La Habana.

Ruiz Plasencia, I. 2015. Historia de las áreas protegidas en Cuba. Centro Nacional de Áreas Protegidas, La Habana (www.snap.cu).

Schwartz, A. and O.H. Garrido. 1972. The lizards of the Anolis equestris complex in Cuba. Studies on the Fauna of Curaçao and other Caribbean Islands 39: 1-86.

Valdés, A. and O.H. Garrido. 1978. Presencia de Rattus (Rodentia: Muridae) en cayos de Cuba. Miscelánea Zoológica 7: 2-3. 